\title{
Cassidulina teretis Tappan and Cassidulina neoteretis new species (Foraminifera): stratigraphic markers for deep sea and outer shelf areas
}

\author{
MARIT-SOLVEIG SEIDENKRANTZ \\ Department of Earth Sciences, University of Aarhus, DK-8000 Århus C, Denmark \\ Present address: Département de Géologie et Océanographie, Université de Bordeaux I, Avenue des Facultés, \\ F-33450 Talence, France
}

\begin{abstract}
Fossil versus Recent specimens allocated to Cassidulina teretis Tappan display slight differences in both ecological distribution and morphology. This has led to a re-examination of specimens from the North Atlantic region. The study was mainly based on scanning electron microscopy. It resulted in the division of the plexus into two species with different stratigraphical and partly different environmental distributions: Cassidulina teretis Tappan and Cassidulina neoteretis $\mathrm{n}$. sp. A distinction between $C$. teretis and C. neoteretis provides a new biostratigraphical marker and may also prove useful in ecological studies.

C. teretis had its first occurrence during the Middle to Upper Miocene and its last well-documented occurrence shortly after the palaeomagnetic Brunhes/Matuyama boundary in the Norwegian Sea, whilst it apparently disappeared from the North Atlantic as early as a little after the Gauss/Matuyama boundary. $C$. neoteretis presumably evolved from $C$. teretis between about 2.0 and $2.3 \mathrm{Ma}$ in the northern North Atlantic and migrated northward inhabiting the Norwegian Sea as C. teretis became extinct here at about $0.7 \mathrm{Ma}$. All Recent specimens belong to C. neoteretis.

Specimens of $C$. teretis have been documented from both arctic and boreal regions in inner shelf to bathyal environments (between about 50 and $2000 \mathrm{~m}$ water depth), whereas the Recent distribution of C. neoteretis is slightly more limited: arctic and cold boreal regions at water depths between 150 and $3000 \mathrm{~m}$, most commonly between 1000 and $1500 \mathrm{~m}$. J. Micropalaeontol. 14(2): 145-157, October 1995.
\end{abstract}

\section{INTRODUCTION}

The species Cassidulina teretis was first described by Tappan (1951) from the Pleistocene of the Gubik Formation, Alaska. Since then the name has been used for specimens from various localities spanning Miocene to Recent times.

Fossil specimens assigned to $C$. teretis are documented from both inner shelf to bathyal environments ranging from arctic to boreal regions. The Recent specimens, which hitherto have been referred to as $C$. teretis on the other hand have a more restricted distribution ranging from outer shelf to bathyal environments in arctic to cold boreal regions. Fossil and Recent specimens also appeared to show small differences in morphology, a fact that has been commented on previously by Mackensen \& Hald (1988). Because of these environmental and morphological differences a re-examination of the taxon was carried out. The purpose of this paper is to describe this morphological difference and the stratigraphical and ecological implications.

\section{MATERIAL}

Authors of several previous studies graciously provided specimens for this study (see Acknowledgements below). Their Recent material is from the central Arctic Ocean, Prince Gustav Adolf Sea, Scoresby Sund, the East Greenland continental margin, the Labrador Sea, the Irminger Basin, the Norwegian Sea northeast of Iceland, the Norwegian continental margin, the Barents Sea, and the Weddell Sea (Fig. 1). Fossil specimens are from Baffin Island (Clyde Foreland and Qivituq), East and Northeast Greenland (Lodin Elv and Kap København), Iceland
(Tjörnes), the northern North Atlantic, the North Sea and the Norwegian Sea (Fig. 1).

About 2000 specimens of Cassidulina have been examined under a light microscope, and approximately 400 of these were later studied using a scanning electron microscope. Systematics follow Nomura (1983a,b) and Loeblich \& Tappan (1988).

\section{NEW PLEISTOCENE BIOSTRATIGRAPHICAL MARKERS}

Specimens assigned to Cassidulina teretis Tappan (1951) have been recorded from the Upper to Middle Miocene to Recent. A comparison of specimens from this interval with the holotype of $C$. teretis (USNM no. 560409, Smithsonian Institution, Washington D.C.) has revealed that a small but general change in the morphology of the specimens has occurred within the stratigraphical record. Specimens that are found prior to this change do not differ from the holotype, whereas the apertural flaps of younger specimens are always much smoother than that of the type specimen of C. teretis (see Systematics below). This difference is small and would not be of any consequence, were it not for the possibility of using this morphological change as a Pleistocene biostratigraphical marker event.

To prevent confusion in distinguishing between the older and younger types a new name is introduced for the latter. The younger type with the smooth apertural flap is given the name Cassidulina neoteretis n. sp. All Recent specimens recorded (see below) belong to $C$. neoteretis. Cassidulina teretis is probably extinct. 


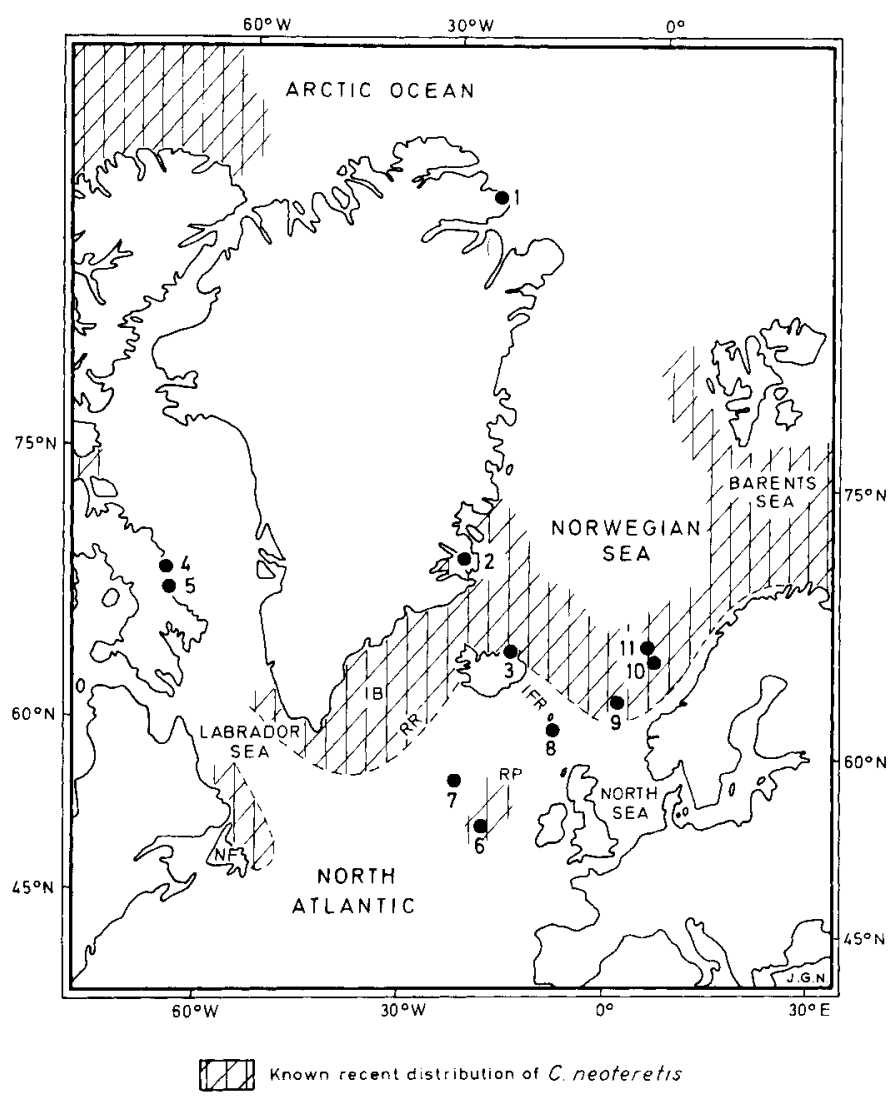

Fig. 1. The known Recent distribution of Cassidulina neoteretis in the North Atlantic region. No data were available from the northern part of the Norwegian Sea or the eastern Arctic Ocean. Sporadic occurrences in the eastern North Atlantic south of the Iceland-Faeroe Ridge are not marked. Locations of borings and outcrops mentioned in this study: 1 Kap København; 2 Lodin Elv; 3 Tjörnes; 4-5 Clyde Foreland and Qivituq, Baffin Island; 6 DSDP Hole 610A; 7 DSDP Hole 552A; 8 Boring 1007, south of the Faeroe Islands; 9 Boring 31-99; 10 ODP Hole 644A; 11 ODP Holes $642 \mathrm{~B} / \mathrm{C}$. IB, Irminger Basin; IFR, Iceland-Faeroe Ridge; RR, Reykjanes Ridge; RP, Rockall Plateau; NF, Newfoundland.

In order to establish exactly when the $C$. teretis LAD and the $C$. neoteretis FAD took place a number of records have been examined. All specimens from examined Neogene records prior to about $2.3 \mathrm{Ma}$ (Figs 1,2 ) have proven to be of true C. teretis (Feyling-Hanssen, 1980, 1985, 1990b; Feyling-Hanssen et al., 1983; Murray, 1987; Schnitker, 1984; Diester-Haass \& Schnitker, 1989; Jansen et al., 1990; Knudsen \& Ásbjörnsdóttir, 1991).

True C. teretis have been recorded until slightly above the palaeomagnetic Brunhes/Matuyama boundary in the North Sea and in ODP Hole 644A from the Vøring Plateau in the Norwegian Sea (Fig. 2) (Sejrup et al., 1987, Jansen et al., 1990). These are the youngest records of C. teretis that have been dated with certainty. The species has been described from possibly younger sediments of the Ymer Formation, northeastern Greenland, but the dating of this deposit is uncertain (Hjort \& Feyling-Hanssen, 1987; Feyling-Hanssen, 1990a).
The oldest record of $C$. neoteretis from the Norwegian Sea is also just above the Bruhnes/Matuyama boundary. This record is from ODP Hole 642C (Osterman \& Qvale, 1989) which is located close to Hole 644A (Fig. 1), and the dating is obtained through correlation with Hole $642 \mathrm{~B}$ from the same site (see Henrich, 1989). None of these records show the transition from $C$. teretis to $C$. neoteretis, but it is likely that in the Norwegian Sea the LAD of C. teretis and first occurrence of $C$. neoteretis both took place at approximately $0.7 \mathrm{Ma}$.

In the North Atlantic (DSDP Hole 552A), on the other hand, $C$. neoteretis already replaced $C$. teretis about 2 million years ago (Fig. 2) (data from Shackleton et al., 1984; Murray, 1987; Diester-Haass \& Schnitker, 1989) (Fig. 2). This is evidence of diachronism in the $C$. teretis LAD and the $C$. neoteretis FAD across the North Atlantic region (Figs $1,2)$.

Unfortunately, $C$. teretis/neoteretis were absent or near absent from Hole 552A during the time interval from about a little after the Gauss/Matuyama boundary (Core 9, section 2; about $2.3 \mathrm{Ma}$ ) to just prior to the palaeomagnetic Reunion event (Core 8 , section 2; about $2.0 \mathrm{Ma}$ ), making an exact placement of the morphologic change from $C$. teretis to $C$. neoteretis impossible. At the same time, the lack of $C$. teretis after about $2.3 \mathrm{Ma}$ implies that the disappearance of C. teretis on Baffin Island and East Greenland close to the Gauss/Matuyama boundary (Fig. 2) (Feyling-Hanssen, 1980, 1985; Feyling-Hanssen et al., 1983) may actually have been a stratigraphic event linked to the extinction of $C$. teretis in the North Atlantic.

The profound similarity between $C$. teretis and $C$. neoteretis indicates that the latter species is probably an evolutionary descendant of the first. Thus, $C$. neoteretis possibly evolved from $C$. teretis in the North Atlantic between about 2.0 and $2.3 \mathrm{Ma}$. It gradually migrated northwards and replaced $C$. teretis in the Norwegian Sea when this species became extinct at about $0.7 \mathrm{Ma}$ BP. (Fig. 2). It is notable that $C$. neoteretis did not migrate to all areas where $C$. teretis had lived. An example is the North Sea where $C$. teretis is a common species in the early Pleistocene. After the LAD of $C$. teretis at about $0.7 \mathrm{Ma}$ the plexus disappeared and $C$. neoteretis does not live in the North Sea today. The only record of $C$. neoteretis from this region is from Boring 3008 from the Gullfaks Field (K.L. Knudsen \& R.W. Feyling-Hanssen, unpubl. data), where C. neoteretis is found in a single sample from the Upper Pleistocene (Fig. 2). This single occurrence should be seen as of only local importance.

The occurrence of $C$. neoteretis in the Weddell Sea of Antarctica (Mackensen \& Douglas, 1989; Mackensen et al., 1990) may be the result of a southward migration during glacial periods.

\section{ECOLOGY}

\section{Cassidulina neoteretis}

Recent records of Cassidulina neoteretis are from polar to cold boreal regions: the Arctic Ocean, the Norwegian and Greenland Seas, the Irminger Basin, the Labrador Sea, the Rockall Plateau, and the Weddell Sea (Fig. 1). The species 


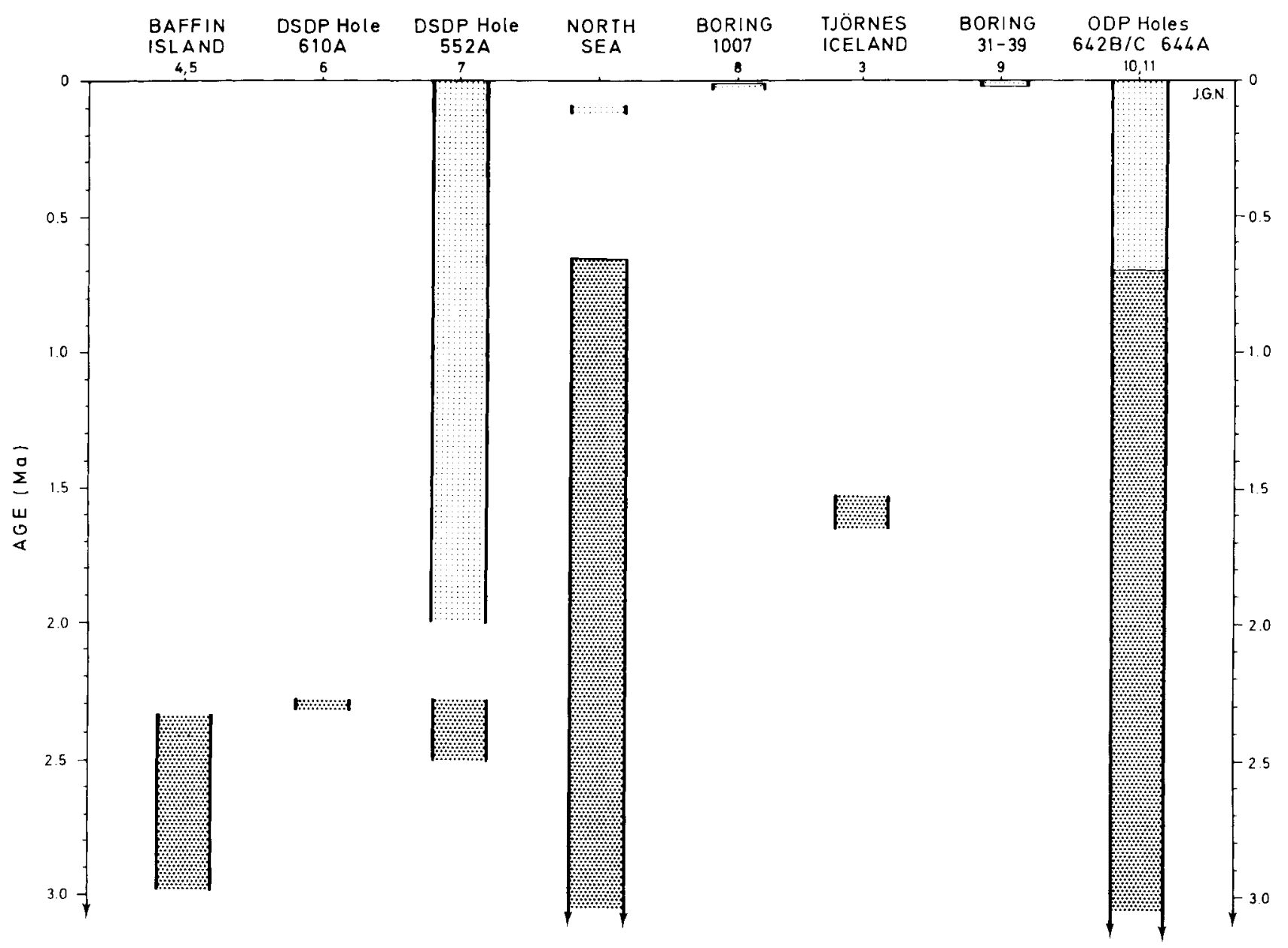

Cassidulina teretis

Cassidulina neoteretis

Fig. 2. Stratigraphical distribution of Cassidulina teretis and Cassidulina neoteretis. Data from Feyling-Hanssen, 1980, 1985; Murray, 1984, 1987; Schnitker, 1984; Jansen \& Bjørklund, 1985; Sejrup et al., 1987; Diester-Haass \& Schnitker, 1989; Osterman \& Qvale, 1989; Jansen et al., 1990; Knudsen \& Ásbjörnsdóttir, 1991; Laursen et al., 1992; Seidenkrantz, 1992; Eiríksson et al., 1992; Christensen, unpublished data. Site numbers and locations are given in Fig. 1.

is recorded from outer shelf and bathyal areas in water depths from about $150-3000 \mathrm{~m}$, but its main occurrence is between 1000 and $1500 \mathrm{~m}$ depth (e.g. Vilks, 1969, as Islandiella teretis (part); Lagoe, 1977; Belanger \& Streeter, 1980; Cole, 1981; Mackensen et al., 1985, 1990; Mackensen, 1987; Mackensen \& Hald, 1988; Mackensen \& Douglas, 1989; Hald \& Steinsund, 1992; Sejrup et al., 1981, as Cassidulina laevigata (part); Schröder-Adams et al., 1990, as C. laevigata; G. Bilodeau, pers. comm., 1992; H. B. Madsen, pers. comm., 1992; D. Penney, pers. comm., 1992).

In the eastern North Atlantic, the southern limit of $C$. neoteretis' main distribution coincides with the IcelandFaeroe Ridge (Fig. 1) (see Jansen \& Bjørklund, 1985; Mackensen et al., 1985; Mackensen, 1987; K. B. Christensen, unpublished data). It is found on the Rockall Plateau but occurs otherwise only sporadically south of this limit (J. F. Weston in Murray, 1987; Diester-Haass \& Schnitker, 1989; own unpublished data). In the western North Atlantic region, its distribution extends south through the Irminger Basin, west of and on top of the Reykjanes Ridge, to the Labrador Sea, where the southernmost record is northeast of Newfoundland (Fig. 1) (Cole, 1981; Schafer \& Cole, 1982; G. Bilodeau, pers. comm., 1992).

Cassidulina neoteretis is infaunal (Jansen et al., 1990; Murray, 1991) and is often associated with fine-grained, organic rich, terrigeneous mud at bottom water temperatures of about $-1{ }^{\circ} \mathrm{C}$ and salinities of about $34.9 \%$ (Mackensen et al., 1985; Mackensen \& Hald, 1988). In the Labrador Sea, it is recorded at bottom water temperatures as high as $3.5^{\circ} \mathrm{C}$ (G. Bilodeau, pers. comm., 1992). The distribution of $C$. neoteretis is generally dependent on the distribution of water masses (Mackensen, 1987), but the species is sometimes restricted to a specific depth interval of a particular water mass. In the Labrador Sea the species 
occurs in the Denmark Strait Overflow Water, but only in the upper part (above $3000 \mathrm{~m}$ ) of the underlying Northeast Atlantic Deep Water (G. Bilodeau, pers. comm., 1992). An accurate record of the distribution of $C$. neoteretis is hampered by its frequent confusion with species such as $C$. laevigata s.l., Paracassidulina neocarinata, and Islandiella helenae Feyling-Hanssen \& Buzas.

Fossil records of $C$. neoteretis exist from both relatively shallow and deep water palaeoenvironments. The only North Sea record of the species is from a single sample of Upper Pleistocene sediments (Fig. 2) presently at a water depth of $140 \mathrm{~m}$; the depositional depth did not exceed $100 \mathrm{~m}$ (K. L. Knudsen \& R. W. Feyling-Hanssen, unpublished data). Its abundant presence in this sample may be due to temporary changes in the current system allowing Norwegian Sea water masses to enter the North Sea.

In the Andfjorden and Malangsdjupet troughs at the Norwegian continental shelf (present water depth: 200$400 \mathrm{~m}), C$. neoteretis was a common species during most of the last deglaciation, when the area was characterized by cold, ice-free surface water. It was replaced by $C$. laevigata s.l. in the Holocene after the establishment of the Norwegian Current with its warm, saline surface water (Mackensen \& Hald, 1988; Jansen \& Bjørklund, 1985). A similar distribution is recorded in a boring at $1125 \mathrm{~m}$ water depth south of the Faeroe Islands (Boring 1007, K. B. Christensen, unpublished data). C. neoteretis is also mainly associated with glacial periods at DSDP Hole 552A in the North Atlantic (Diester-Haass \& Schnitker, 1989).

Contrary to this, records from deep water in the Norwegian Sea show an immigration of $C$. neoteretis to the Norwegian Sea during the last deglaciation and a temporary decrease in its frequency during the Younger Dryas cold period (Jansen \& Bjørklund, 1985; Jansen \& Erlenkeuser, 1985).

Cassidulina neoteretis is, thus, an indicator of cold water masses in the northern North Atlantic and on the Norwegian shelf, while it may characterize ameliorated conditions in deep water areas of the Norwegian Sea.

\section{Cassidulina teretis}

Cassidulina teretis is equally abundant in the fossil record of deep sea and shelf areas with palaeo-water depths of 50-2000 m (Murray, 1984; Schnitker, 1984, Diester-Haass \& Schnitker, 1989; Feyling-Hanssen, 1985, 1990a,b; Knudsen \& Ásbjörnsdóttir, 1991). Cassidulina teretis had its first occurrence in the Norwegian Sea and the North Sea during the warm climate of the Middle to Upper Miocene (Jansen et al., 1990; Laursen et al., 1992). The species characterizes pre-glacial Pliocene deposits from the North Sea, Canada and Greenland and decreases in frequency at the onset of Northern Hemisphere glaciations (e.g. Feyling-Hanssen, 1985; Knudsen \& Ásbjörnsdóttir, 1991; Seidenkrantz, 1992). In the North Atlantic the species presumably disappeared near the onset of the Northern Hemisphere glaciations at about 2.4 Ma. In northeastern Greenland, it is recorded only in interglacial deposits (Feyling-Hanssen, 1990a).

These records show that $C$. teretis may be considered a warm-water indicator in polar and possibly also in boreal regions. Hence, $C$. teretis had a habitat relatively similar to that of $C$. neoteretis, but it more often inhabited shallow and relatively warm water deposits. Thus, $C$. teretis seems to have had a wider ecological range than $C$. neoteretis.

\section{SYSTEMATIC DESCRIPTIONS}

Suborder Rotaliina Delage \& Hérouard, 1896

Family Cassidulinidae d'Orbigny, 1839

Subfamily Cassidulininae d'Orbigny, 1839

Genus Cassidulina d'Orbigny, 1826

Cassidulina neoteretis $\mathrm{n}$. $\mathrm{sp}$.

(Pl. 1, figs 1-6; Pl. 2, figs 1-14; Pl. 3, figs 1-8; Pl. 5, figs 1-3)

1977 Cassidulina teretis sensu Lagoe (not Tappan): 127, pl. 5, figs $15,16$.

1980 Cassidulina teretis sensu Rodrigues et al. (not Tappan): 59, pl. 2, figs 1, 3, 5; pl. 5, figs 1, 4, 7; pl. 6, figs 7, 10 .

1981 Cassidulina laevigata (part) sensu Sejrup et al. (not d'Orbigny): 290, pl. 1, fig. 5 .

1987 Cassidulina teretis sensu Mackensen (not Tappan): pl. 10 , figs $\mathrm{e}, \mathrm{f}, \mathrm{k}, \mathrm{l}$.

1988 Cassidulina teretis sensu Mackensen \& Hald (not Tappan): 16-24, pl. 1, figs 8-15.

Diagnosis. Small, lenticular Cassidulina with 4 to 5 chamber pairs in the last whorl, a clear umbilical boss and a smooth triangular apertural plate.

Holotype. Specimen (MGUH no. 22189) from Boring 1007, sample 19. Housed at the Department of Earth Sciences, University of Aarhus.

Paratypes. 10 specimens (Paratypes 1-10; MGUH nos 22190-22199) are housed at the Department of Earth Sciences, University of Aarhus; 2 specimens (Paratypes 11 and 12; nos ZF 5010 and ZF 5011) are housed at the Natural History Museum, London, UK; and 2 specimens (Paratypes 13 (primary) and 14 (secondary); U.S. National Museum nos USNM 483228 and USNM 483229) are housed at the Smithsonian Institution, Washington, DC, USA. All specimens are from Boring 1007, sample 19.

\section{Explanation of Plate 1}

Light microscope photographs. Figs 1-6. Cassidulina neoteretis n. sp., $\times 105.1$ a, b: Holotype (MGUH no. 22189). 2: Paratype 4 (MGUH no. 22193). 3a, b: Paratype 5 (MGUH no. 22194). 4a, b: Paratype 6 (MGUH no. 22195). 5a, b: Paratype 7 (MGUH no. 22196). 6: Paratype 3 (MGUH no. 22192). Figs 7-9. Cassidulina laevigata carinata Silvestri, specimens from the Holocene of the Skagerrak, Denmark (MGUH nos $22200,22201,22202), \times 105$. Figs 10-11. Paracassidulina neocarinata Thalmann, specimens from the Recent of the Emerald Basin off the coast of Halifax (MGUH nos 22203, 22204), × 105. Figs 12-13. Cassidulina teretis Tappan, specimens from the Pliocene of the Clyde Foreland, Baffin Island (MGUH nos 22205, 22206), $\times 82$. Figs 14a-c. Original drawings of the holotype of Cassidulina teretis (from Tappan, 1950, pl.1, figs $30 \mathrm{a}-\mathrm{c}), \times 68$. 

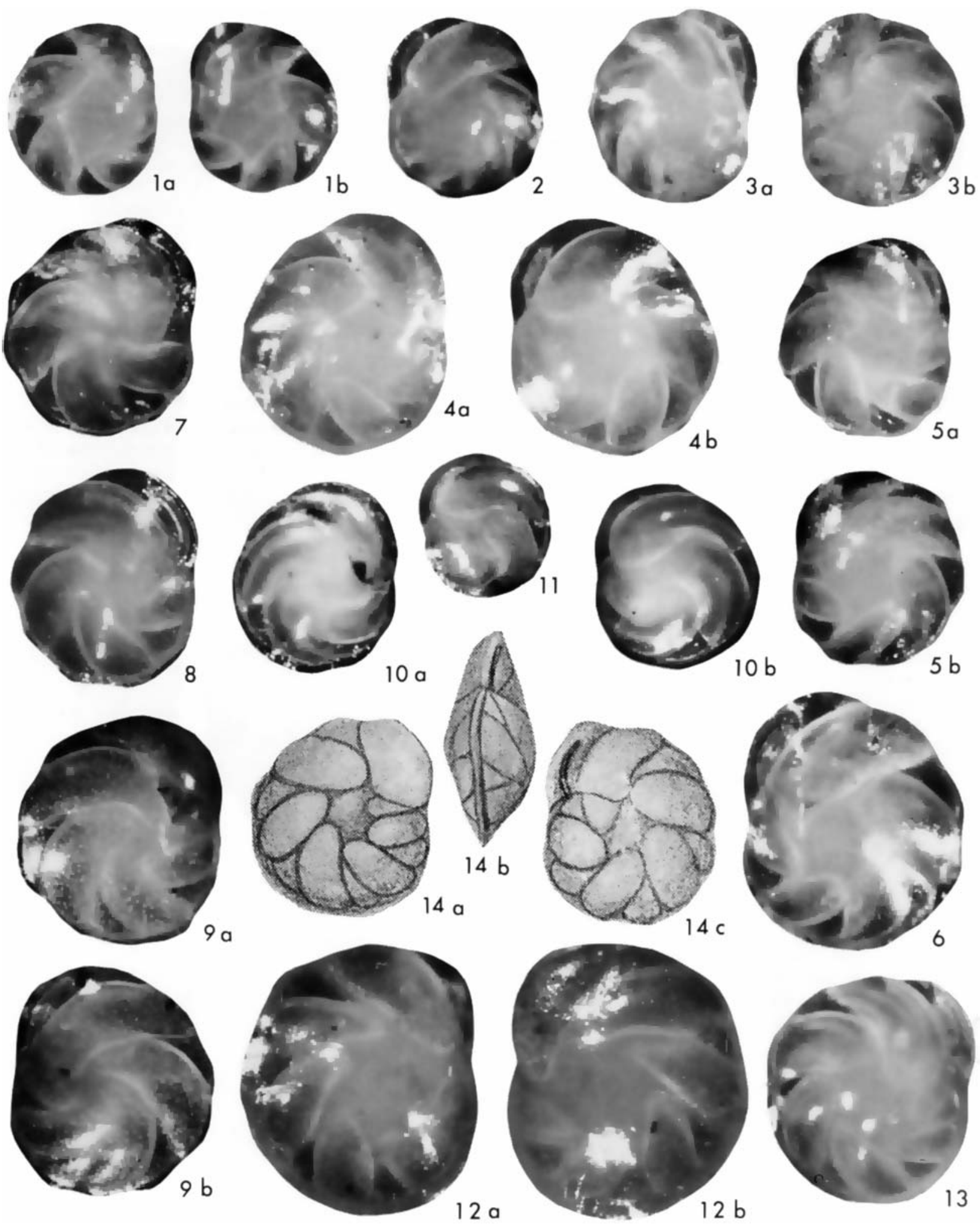

$10 \mathrm{~b}$
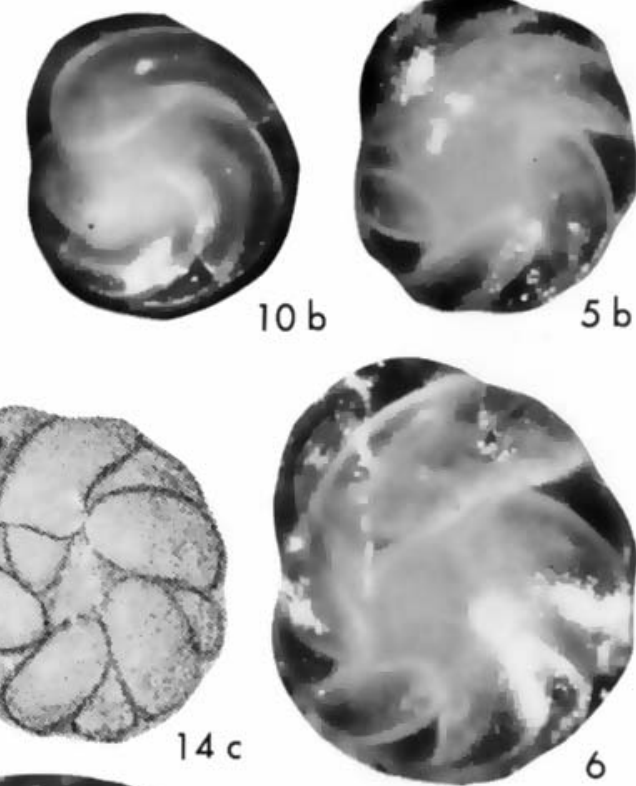

Plate 1 

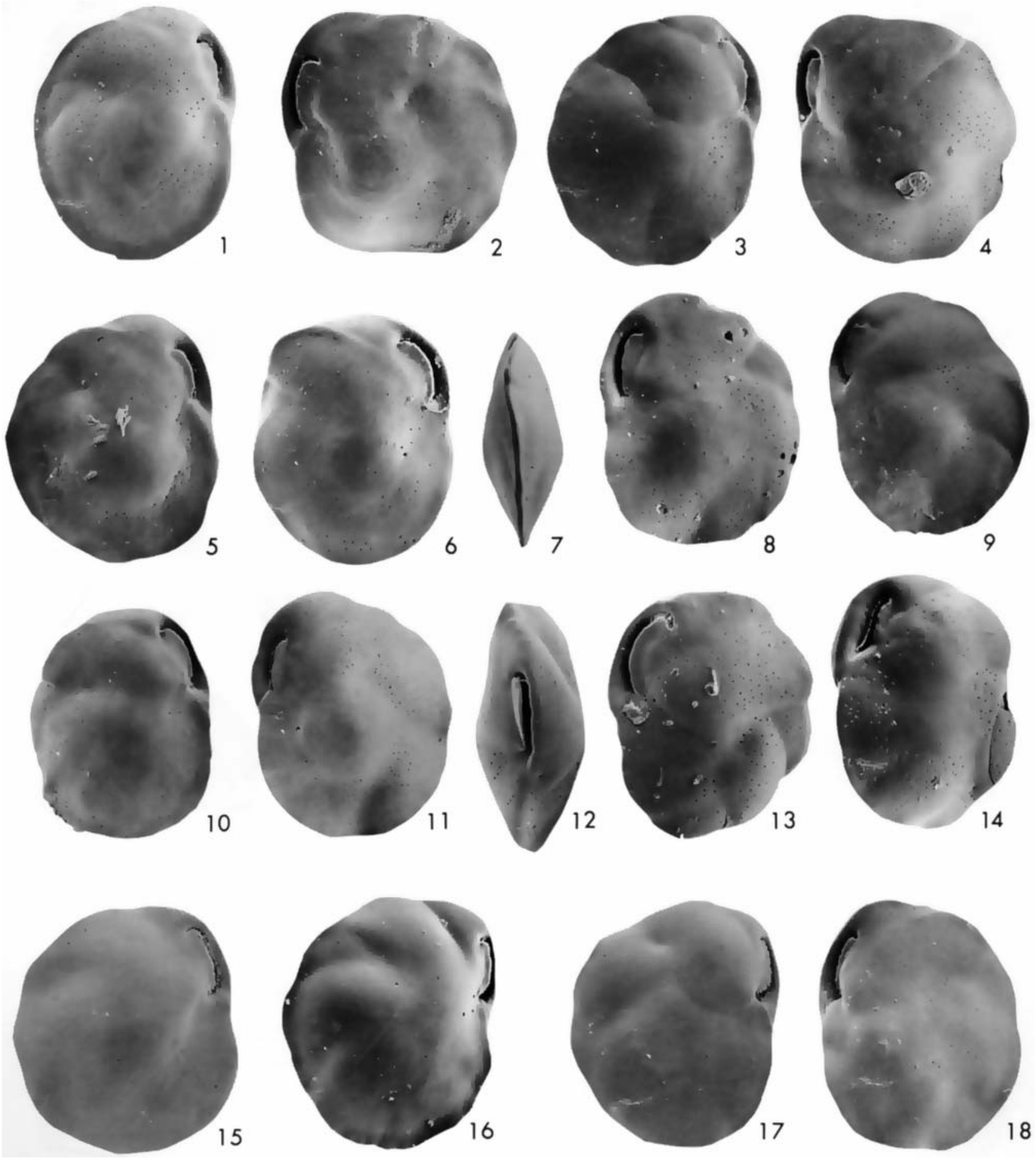

Plate 2 
Material. Several hundred specimens from various localities.

Type locality and horizon. Boring 1007 off the Faeroe Islands $\left(60^{\circ} 44.69^{\prime} \mathrm{N}, 4^{\circ} 30.89^{\prime} \mathrm{W}\right)$, sample 19 (Late Weichselian). Recent water depth $1125 \mathrm{~m}$.

Description. Test lenticular, biconvex with an acute, slightly undulating, peripheral margin. Umbilical boss of milky, semitranslucent shell material on each side. Eight to ten chambers (frequently 10) in the final whorl, biserially arranged in 4 to 5 alternating pairs, each chamber appearing large, rounded rhomboid to ovate and reaching to the umbilical boss on one side of the test, and small and subtriangular on the other side. Sutures distinct, thickened, but not limbate, slightly depressed and outlining the chamber. Wall calcareous, hyaline or opaque, and optically granular. Surface smooth with relatively small, rounded, pores evenly distributed on the chamber walls but with no pores on the umbilical boss or along the sutures. Aperture an elongate, narrow slit extending from the base of the final chamber in a crescent paralleling the outer margin of the chamber, reaching $2 / 3$ to $3 / 4$ the distance from the base of the chamber to the peripheral keel. A subtriangular apertural plate with a smooth edge, formed by the infolded chamber wall, lies along the inner margin and partly covers the aperture (a type $\mathrm{H} 1$ aperture with a slight tendency to a type $\mathrm{H} 2$ aperture, according to definition by Nomura (1983a)) (Pl. 3, figs 1-8). A narrow, serrate ridge lies adjacent to the outer margin of the aperture (Pl. 3, fig. 7).

Dimensions. Holotype: greatest diameter: $300 \mu \mathrm{m}$, least diameter: $250 \mu \mathrm{m}$, greatest thickness: $130 \mu \mathrm{m}$. Dimensions for 80 other specimens (average value in brackets): greatest diameter: $230-410 \mu \mathrm{m}(300 \mu \mathrm{m})$, least diameter: $200-360 \mathrm{~m} \quad(260 \mu \mathrm{m})$, greatest thickness: $130-200 \mu \mathrm{m}$ $(150 \mu \mathrm{m})$.

Variation. There is very little variation within this species. The edge of the apertural plate, however, varies between being totally smooth (normal) and having very small, rounded serrata as in the specimen Pl. 3, fig. 5. Furthermore, the shape of the apertural plate varies between triangular (normal) and crescent-shaped. The periphery may have a keel or carina, which may have small ruffles (see Pl. 2, fig. 9).

Affinities. Cassidulina neoteretis shows close resemblance to Cassidulina teretis Tappan, 1951, but differs in having a smooth, normally somewhat broader apertural plate with a more distinct angle at the marginal end giving a subtriangular shape, while $C$. teretis has a crescent-shaped, serrate, apertural plate (see PI. 4, figs 1-5). Furthermore,
C. neoteretis is normally smaller in size. The differences are small, but are in well-preserved specimens detectable in both light microscope and scanning electron microscope.

Cassidulina neoteretis shows some resemblance to Cassidulina laevigata laevigata d'Orbigny and C. laevigata carinata Silvestri but the latter two taxa generally lack an umbilical boss, have longer and more curved chambers, larger pores and a distinctly serrate crescent-shaped apertural plate (see Pl. 1, figs 7-9; Pl. 4, figs 6, 8; Pl. 5, figs 5, 7,8 ). The carinate type $C$. laevigata carinata Silvestri may have an umbilical boss but this is normally smaller and less clearly defined than that of $C$. neoteretis (see Pl. 1, fig. 8) (see also Mackensen \& Hald, 1988).

Cassidulina neoteretis also shows some affinity to Paracassidulina neocarinata (Thalmann), but this species has more ovate and curved chambers which are generally fewer in numbers (4 pairs). Furthermore, the aperture of $P$. neocarinata is a long, narrow slit covered by a very thin, smooth lip (type $G$ aperture, according to definition by Nomura, 1983a), and both the umbilical boss and the pores are very small (see emended description by Nomura (1983b) and Pl. 1, figs 10-11; Pl. 4, fig. 7; Pl. 5, figs 6, 9, 10).

Cassidulina neoteretis shows only superficial affinity to Islandiella helenae Feyling-Hanssen \& Buzas (1976) as the latter species has a translucent, distinctly optically radial wall structure, a more rounded outline of the chambers and a shorter rounded aperture with a free tongue projecting out of it (type A1 aperture, according to definition by Nomura (1983a)).

Cassidulina teretis Tappan, 1951

(Pl. 1, figs 13-15; Pl. 2, figs 15-18; Pl. 4, figs 1-5; Pl. 5, fig. 4)

1951 Cassidulina teretis Tappan: 7-8, pl. 1, fig. 30.

1980 Cassidulina teretis Tappan; Feyling-Hanssen: pl. 4, figs $10,11,15$.

1983 Cassidulina cf. teretis Tappan; Feyling-Hanssen et al.: 105, pl. 1, figs 6-9, 11-13.

Remarks. A thorough description of this species was made by Tappan (1951). Only an emendation of the apertural description will be added here: Tappan (1951) described the aperture as "elongate, extending from the base of the final chamber in a crescent paralleling the anterior margin of the chamber, reaching nearly three-fourths the distance from the base of the chamber to the peripheral keel'. The aperture is partly covered by a narrow, serrate plate formed by the infolded chamber wall (type $\mathrm{H} 1$ aperture, according to definition by Nomura (1983a)). The serration along the edge of the apertural plate is not dissimilar, but

\section{Explanation of Plate 2}

Scanning electron microscope photographs. Figs 1-14. Cassidulina neoteretis n. sp. 1-12: Specimens from the Upper Weichselian of Boring 1007 off the Faeroe Islands, North Atlantic (MGUH nos 22207-22218), $\times 130,135,110,130,95,135,95,135,110,120,135,150.13:$ (MGUH no. 22219) Specimen from the Lower Pleistocene at DSDP Hole 552A, $\times 160$. 14: Specimen from Recent sediments northeast of Iceland (MGUH no. 22220), $\times 95$. Figs 15-18. Cassidulina teretis Tappan. 15: Specimen from the Upper Pliocene at the Gullfaks field, North Sea (MGUH no. 22221), $\times 95$. 16: Specimen from the Upper Pliocene at DSDP Hole 552A (MGUH no. 22222), $\times 120$. 17: Specimen from just above the palaeomagnetic Brunhes/Matuyama boundary (lowermost Middle Pleistocene) at ODP Hole 644A (MGUH no. 22223), $\times 75$. 18: Specimen from the Upper Miocene at ODP Hole 642B (MGUH no. 22224), $\times 95$. 

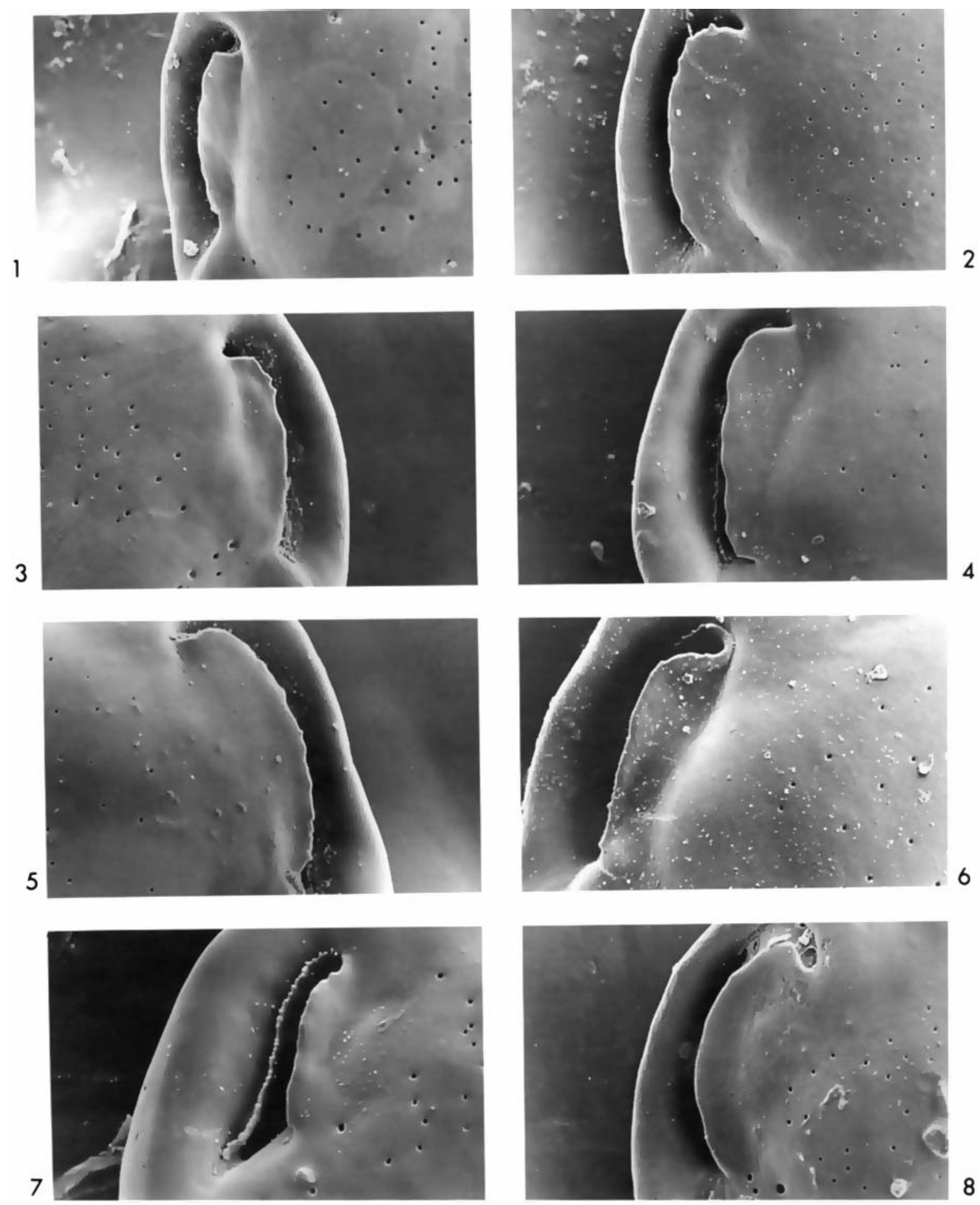

Plate 3 
more distinct (though also more sporadic) and with bigger teeth than that of Cassidulina laevigata s.l. d'Orbigny (see Mackensen \& Hald, 1988 and compare Pl. 4, figs $1-5$ and Pl. 4 figs 6,8 ). The serration is most prominent in the best preserved specimens. This documents that the serration is a primary character of the species and is not due to post mortem dissolution. The size of the specimens measured in this study varies with the greatest diameter between 250 and $550 \mu \mathrm{m}$, the bulk of the specimens, however, having a greatest diameter of $400-450 \mu \mathrm{m}$.

In studies from some localities from Greenland and the North Sea a somewhat smaller variety of Cassidulina teretis has been separated from $C$. teretis as Cassidulina cf. teretis (Feyling-Hanssen et al., 1983; Funder et al., 1985; Seidenkrantz, 1992). Cassidulina cf. teretis differs from the typical $C$. teretis by its often smaller size and smaller umbilical boss. A thorough examination of the two types have, however, shown transitional forms between them. Furthermore, there is no difference in the shape of the aperture. This leads to the conclusion that $C$. cf. teretis is a morphological variation of $C$. teretis.

Examination of paratypes of $C$. teretis have shown that several of these belong to the genus Islandiella (I. inflata and I. helenae) (USNM no. 560413 and part of no. 560413; see also Feyling-Hanssen \& Buzas, 1976).

\section{SUMMARY}

Specimens which until now have been assigned to Cassidulina teretis belong to two different species, Cassidulina teretis Tappan and Cassidulina neoteretis $\mathrm{n}$. $\mathrm{sp}$. The most apparent difference between these is the shape of the apertural flap, but the latter species is also generally smaller in size. The differences are small, but are detectable in well-preserved specimens in both light microscope and scanning electron microscope.

Cassidulina neoteretis presumably evolved from $C$. teretis in the North Atlantic between about 2.0 and $2.3 \mathrm{Ma}$ and migrated northwards at a later time. The LAD of $C$. teretis and the first occurrence of $C$. neoteretis in the Norwegian Sea was during the Middle Pleistocene, just above the palaeomagnetic Brunhes/Matuyama boundary (Fig. 2). The distinction between $C$. teretis and $C$. neoteretis thereby allows the establishment of a new biostratigraphical marker.

Cassidulina teretis lived in both deep-sea and neritic palaeoenvironments of boreal to subarctic areas, whereas $C$. neoteretis is mainly a deep-sea species found in arctic and antarctic to subarctic water masses.

\section{ACKNOWLEDGEMENTS}

This study could not have been undertaken without the aid of the many persons who provided material for this study:
Lovisa Ásbjörnsdóttir, Guy Bilodeau, Martin Buzas, Karen Bæk Christensen, David L. Clark, Rolf W. Feyling-Hanssen, Morten Hald, Eystein Jansen, Karen Luise Knudsen, Martin Lagoe, Gitte Vestergaard Laursen, Andreas Mackensen, Hanne B. Madsen, John W. Murray, Lisa Osterman, David N. Penney, Else Reither, Detmar Schnitker, Hans Petter Sejrup, Nicholas J. Shackleton, Jorunn Sjøholm, and Per Ivar Steinsund. My sincere thanks also to Karen Luise Knudsen, David N. Penney, Martin A. Buzas, and the journal reviewer John R. Haynes for critically reading the manuscript and providing valuable comments, to Svend Meldgaard Christiansen for the photographs and to Jette Gissel Nielsen for preparing the drawings. This study was funded by the Danish Natural Science Research Council.

\section{Manuscript received August 1993 Manuscript accepted April 1994}

\section{REFERENCES}

Belanger, P. E. \& Streeter, S. S. 1980. Distribution and ecology of benthic foraminifera in the Norwegian-Greenland Sea. Marine Micropaleontology, Amsterdam, 5: 401-428.

Cole, F. E. 1981. The Bathyal Zone Benthonic Foraminiferal Species Off Northeast Newfoundland. Bedford Institute of Oceanography, Report Series BI-R-81-7, Dartmouth, Halifax, 1-122.

Diester-Haass, L. \& Schnitker, D. 1989. Plio-Pleistocene sedimentation regimes leading to chalk-marl-cycles in the North Atlantic (DSDP Site 552 - Hole 552A). Geologische Rundschau, Stuttgart, 78: 959-985.

Eiríksson, J., Knudsen, K. L. \& Vilhjalmsson, M. 1992. An early Pleistocene glacial-interglacial cycle in the Breidavík Group on Tjörnes, Iceland: Sedimentary facies, foraminifera, and molluscs. Quaternary Science Reviews, Oxford, 11: 733-757.

Feyling-Hanssen, R. W. 1980. Microbiostratigraphy of young Cenozoic marine deposits of the Qivituq Peninsula, Baffin Island. Marine Micropaleontology, Amsterdam, 5: 153-184.

Feyling-Hanssen, R. W. 1985. Late Cenozoic marine deposits of East Baffin Island and East Greenland: microbiostratigraphy, correlation, and age. In Andrews, J. T. (Ed.), Quaternary Environments, Eastern Canadian Arctic, Baffin Bay and Western Greenland, 354-393, Allen \& Unwin, Boston.

Feyling-Hanssen, R. W. 1990a. A remarkable foraminiferal assemblage from the Quaternary of northeast Greenland. Bulletin of the Geological Society of Denmark, Copenhagen, 38: 101-107.

Feyling-Hanssen, R. W. 1990b. Foraminiferal stratigraphy in the Plio-Pleistocene Kap København Formation, North Greenland. Meddelelser om Grønland, Geoscience, Copenhagen, 24: 1-32.

Feyling-Hanssen, R. W. \& Buzas, M. A. 1976. Emendation of Cassidulina and Islandiella helenae new species. Journal of Foraminiferal Research, Lawrence, Kansas, 6: 154-158.

Feyling-Hanssen, R. W., Funder, S. F. \& Petersen, K. S. 1983. The Lodin Elv Formation: a Plio-Pleistocene occurrence in Greenland. Bulletin of the Geological Society of Denmark, Copenhagen, 31: $81-106$.

Funder, S., Abrahamsen, N., Bennike, O. \& Feyling-Hanssen, R.W. 1985. Forested Arctic: Evidence from North Greenland. Geology, Boulder, Colorado, 13: 542-546.

\section{Explanation of Plate 3}

Scanning electron microscope photographs. Figs 1-8. Apertural section of Cassidulina neoteretis n. sp, note smooth, broad apertural plate. 1-6: Specimens from the Upper Weichselian, Boring 1007 south of the Faeroe Islands (MGUH nos 22216, 22208, 22207, 22214, 22210, 22225), $\times 550,450,400,500,400,650.7$ : Specimen from Recent sediments northeast of Iceland (MGUH no. 22220), $\times 500$, note narrow serrate ridge adjacent to the outer margin. 8: Specimen from the Lower Pleistocene at DSDP Hole 552A (MGUH no. 22219 ), $\times 450$. 

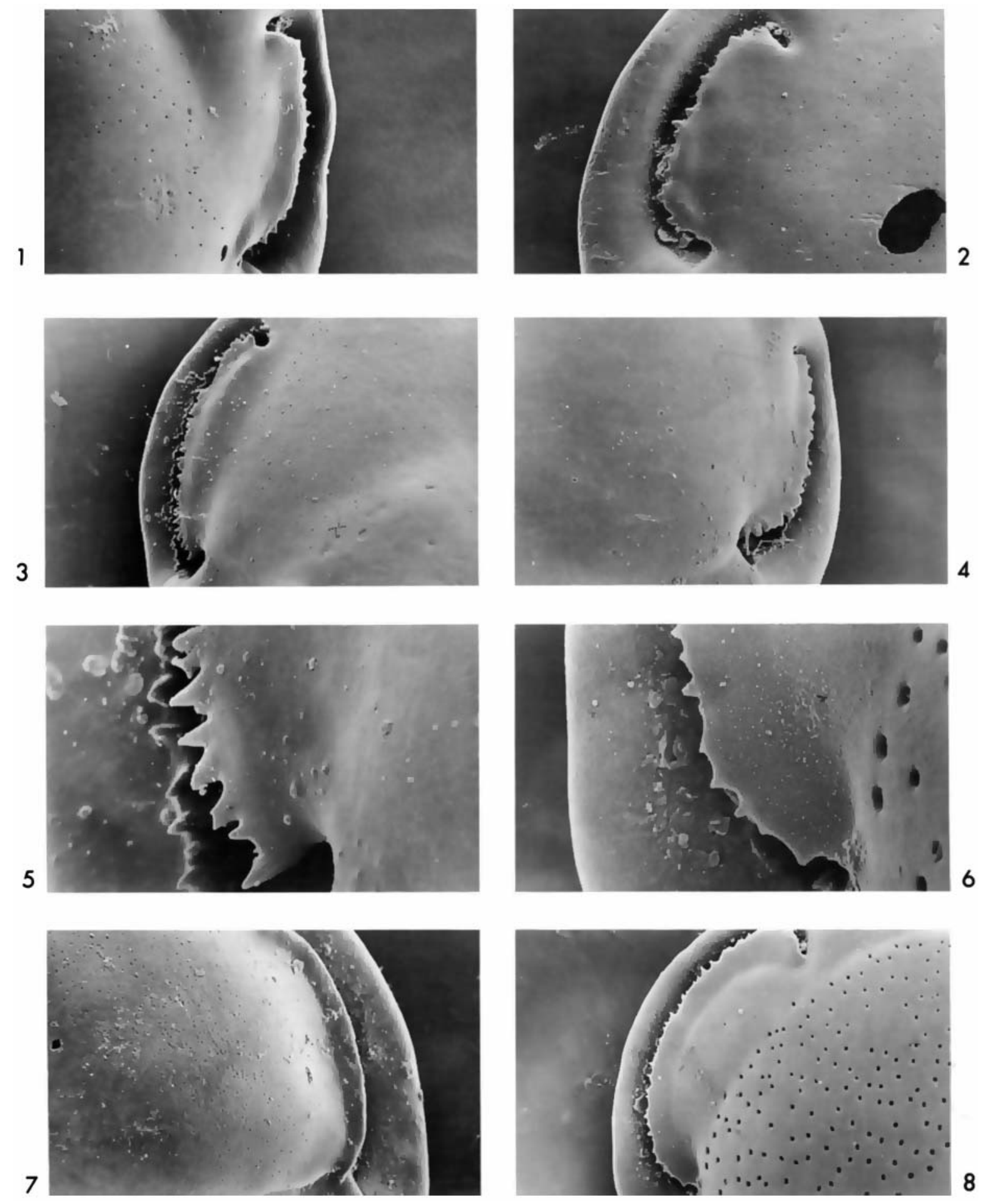

Plate 4 
Hald, M. \& Steinsund, P. I. 1992. Distribution of surface sediment benthic foraminifera in the southwestern Barents Sea. Journal of Foraminiferal Research, Hanover, Pennsylvania, 22: 347-362.

Henrich, R. 1989. Glacial/interglacial cycles in the Norwegian Sea: sedimentology, paleoceangraphy, and evolution of Late Pliocene to Quaternary Northern Hemisphere climate. In Eldholm, O., Thiede, J., Taylor, E., et al. (Eds), Proceedings of the Ocean Drilling Program. Scientific Results, College Station, TX (Ocean Drilling Program), 104: 189-232.

Hjort, C. \& Feyling-Hanssen, R. W. 1987. The Ymer-Formationan interglacial scquence in northeasternmost Greenland. Polar Research n.s., Oslo, 5: 347-350.

Jansen, E. \& Bjørklund, K. R. 1985. Surface ocean circulation in the Norwegian Sea 15,000 B.P. to present. Boreas, Oslo, 14: 243-257.

Jansen, E. \& Erlenkeuser, H. 1985. Ocean circulation in the Norwegian Sea during the last deglaciation: isotopic evidence. Palaeogeography Palaeoclimatology Palaeoecology, Amsterdam, 49: $189-206$.

Jansen, E., Sjøholm, J., Bleil, U. \& Erichsen, J. A. 1990. Neogene and Pleistocene glaciations in the northern hemisphere and Late Miocene-Pliocene global ice volume fluctuations: Evidence from the Norwegian sea. In Bleil, U. \& Thiede, J. (Eds), Geological History of the Polar Oceans: Arctic Versus Antarctic, 677-705. Kluwer Academic Publishers, the Netherlands.

Knudsen, K. L. \& Ásbjörnsdóttir, L. 1991. Plio-Pleistocene foraminiferal stratigraphy and corrclation in the Central North Sea. Marine Geology, Amsterdam, 101: 113-124.

Lagoe, M. B. 1977. Recent benthic foraminifera from the central Arctic Ocean. Journal of Foraminiferal Research, Lawrence, Kansas, 7: 106-129.

Laursen, G. V., Heilmann-Clausen, C. \& Thomsen, E. 1992. Cenozoic biostratigraphy of the eastern North Sea based on foraminifera, dinoflagellates, and calcareous nannofossils. Final biostratigraphical report of the CENOS-project. Unpublished report, Department of Earth Sciences, University of Aarhus, Ârhus.

Loeblich Jr, A. R. \& Tappan, H. 1988. Foraminiferal Genera and Their Classification. Van Nostrand Reinhold Compagny, New York.

Mackensen, A. 1987. Bentische Foraminiferen aus dem IslandSchottland Ruicken: Umwelt-Anzeiger an der Grenze zweier ozeanischer Räume. Paläontologische Zeitschrift, Stuttgart, 61: 149-179.

Mackensen, A. \& Douglas, R. G. 1989. Down-core distribution of live and dead deep-water benthic Foraminifera in box cores from the Weddell Sea and the California continental borderland. Deep-Sea Research, Oxford, 36: 879-900.

Mackensen, A., Grobe, H., Kuhn, G. \& Fütterer, D. K. 1990. Benthic foraminiferal assemblages from the eastern Weddell Sea between 68 and $73^{\circ} \mathrm{S}$ : Distribution, ecology and fossilization potential. Marine Micropaleontology, Amsterdam, 16: 241-283.
Mackensen, A. \& Hald, M. 1988. Cassidulina teretis Tappan and C. laevigata d'Orbigny: Their modern and late Quaternary distribution in Northern Seas. Journal of Foraminiferal Research, Lawrence, Kansas, 18: 16-24.

Mackensen, A., Sejrup, H. P. \& Jansen, E. 1985. The distribution of living benthic Foraminifera on the continental slope and rise off Southwest Norway. Marine Micropaleontology, Amsterdam, 9: 275-306.

Murray, J. W. 1984. Paleogene and Neogene benthic foraminifers from Rockall Plateau. In Roberts, D. G., Schnitker, D. et al., Initial Report of the Deep Sea Drilling Project, 81: 503-534. U.S. Government Printing Office, Washington DC.

Murray, J. W. 1987. Benthic foraminifers and Neogene bottomwater masses at deep sea drilling project leg 94 North Atlantic Sites. In Ruddiman, W. F., Kidd, R. B., Thomas, E. et al., Initial Report of the Deep Sea Drilling Project, 81: 965-979. U.S. Government Printing Office, Washington DC.

Murray, J. W. 1991. Ecology and Palaeoecology of Benthic Foraminifera. Longman Scientific and Tecnical, Longman Group UK Limited, Burnt Mill, Harlow, England, 397 pp.

Nomura, R. 1983a. Cassidulinidae (Foraminiferida) from the Uppermost Cenozoic of Japan (Part 1). Tohuku University Science Reports, 2nd series (Geology), Sendai, 53: 1-101.

Nomura, R. 1983b. Cassidulinidae (Foraminiferida) from the Uppermost Cenozoic of Japan (Part 2). Tohuku University Science Reports, 2nd series (Geology), Sendai, 54: 1-193.

Osterman, L. \& Qvale, G. 1989. Benthic foraminifers from the Vøring Plateau (ODP Leg 104). In Eldholm, O., Thiede, J. \& Taylor, E., et al. (Eds), Proceedings of the Ocean Drilling Program, Scientific Results, College Station, TX (Ocean Drilling Program), 104: 745-768.

Rodrigues, C. G., Hooper, K. \& Jones, P.C. 1980. The apertural structures of Islandiella and Cassidulina. Journal of Foraminiferal Research, Lawrence, Kansas, 10: 48-60.

Schafer, C. T. \& Cole, F. E. 1982. Living benthic foraminifera distributions on the continental slope and rise of Newfoundland, Canada. Bulletin of the Geological Society of America. Boulder, Colorado, 93: 207-217.

Schnitker, D. 1984. High resolution records of benthic foraminifera in the Late Neogene of the northeastern Atlantic. In Roberts, D. G., Schnitker, D. et al., Initial Report of the Deep Sea Drilling Project, 81: 611-622. U.S. Government Printing Office, Washington DC.

Schröder-Adams, C. J., Cole, F. E., Medioli, F. S., Mudie, P. J., Scott, D. B. \& Dobbin, L. 1990. Recent Arctic shelf foraminifera: Seasonally ice covered vs. perennially ice covered areas. Journal of Foraminiferal Research, Lawrence, Kansas, 20: 8-36.

Seidenkrantz, M.-S. 1992. Plio-Pleistocene paleoecology and stratigraphy in the northeasternmost North Sea. Journal of Foraminiferal Research, Hanover, Pennsylvania, 22: 363-378.

Sejrup, H. P., Aarseth, I., Ellingsen, K. L., Reither, E., Jansen, E.,

\section{Explanation of Plate 4}

Scanning electron microscope photographs Apertural sections. Figs 1-5. Cassidulina teretis Tappan, note distinct teeth on plate. 1: Specimen from the Upper Pliocene at DSDP Hole 552A (MGUH no. 22222), $\times 500 ; 2$ : Specimen from the Upper Pliocene at the Gullfaks field, North Sea (MGUH no. 22226), $\times 300 ; 3-5$; Specimens from the Lower Pleistocene at ODP Hole 644A (MGUH nos 22227,22223 ), 3, $4 \times 250,5$ Closeup of Fig. 3, $\times 700$. Figs 6, 8. Cassidulina laevigata carinata Silvestri, note small teeth on the apertural plate; specimen from the Holocene of the Skagerrak, Denmark (MGUH no. 22228), 6: Close-up of Fig. $8, \times 700,8 \times 350$. Fig. 7. Paracassidulina neocarinata Thalmann, note smooth, narrow lip; specimen from the Gulf of Maine, U.S.A. (MGUH no. 22229), $\times 450$.

\section{Explanation of Plate 5}

Scanning electron microscope photographs. Figs 1-6. Density and size of porcs, $\times 900.1-3$ : Cassidulina neoteretis $\mathrm{n}$. sp. from the Upper Weichselian, Boring 1007 south of the Faeroe Islands (MGUH nos 22217, 22207, 22208). 4: Cassidulina teretis Tappan from the Upper Miocene at ODP Hole 642B (MGUH no. 22224). 5: Cassidulina laevigata carinata Silvestri, from the Holocene in the Skagerrak, Denmark (MGUH no. 22229). 6: Paracassidulina neocarinata Thalmann, from the Holocene of Gulf of Maine, U.S.A. (MGUH no. 22230). Figs 7-8. Cassidulina laevigata carinata Silvestri from the Holocene in the Skagerrak, Denmark (MGUH nos 22230, 22228), $\times 100,105$. Figs 9-10. Paracassidulina neocarinata Thalmann from the Holocene of the Gulf of Maine, U.S.A (MGUH nos 22229, 22231), X150. 

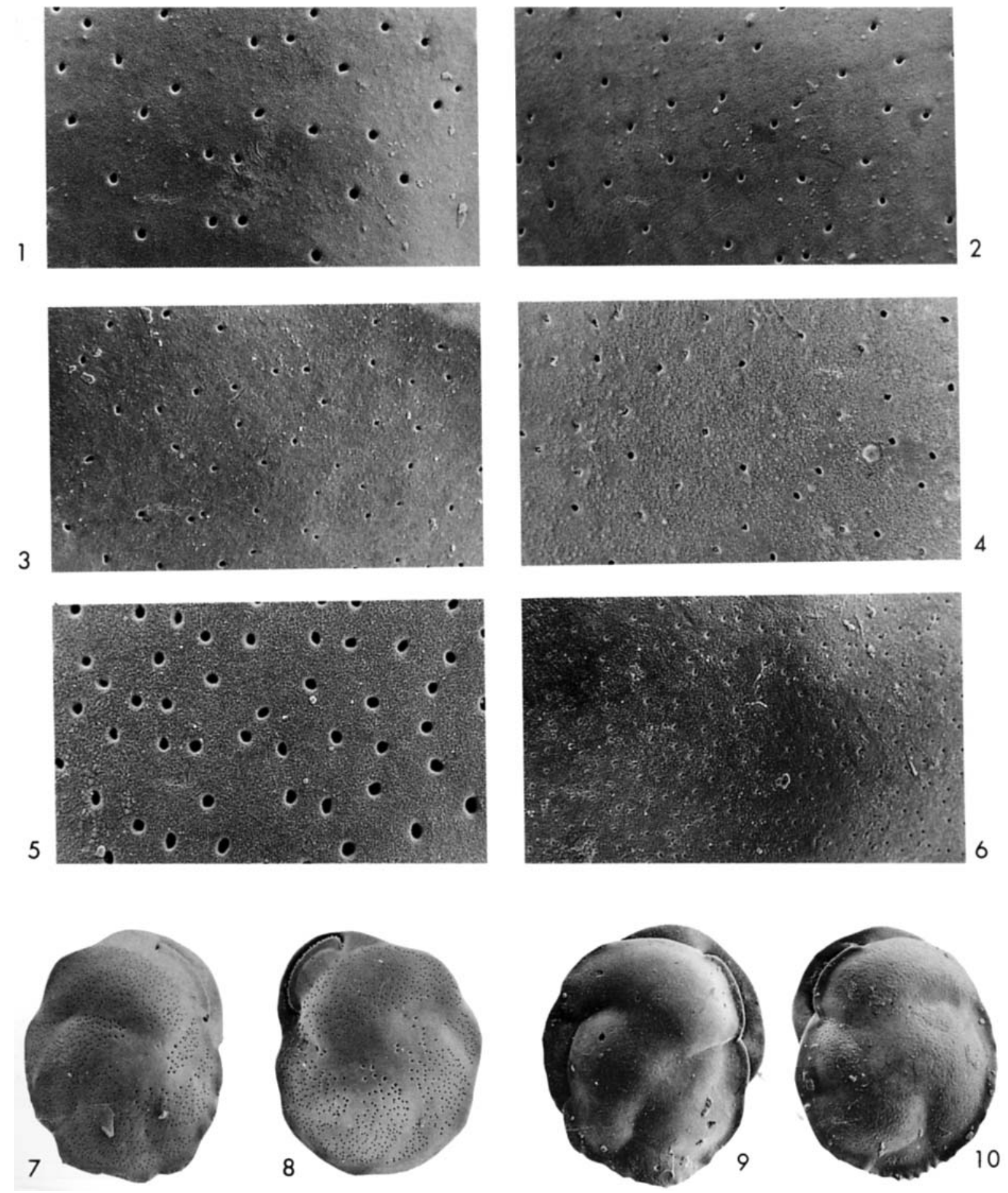

Plate 5 
Løvlie, R., Bent, A., Brigham-Grette, J., Larsen, E. \& Stoker, M. 1987. Quaternary stratigraphy of the Fladen area, central North Sea: a multidisciplinary study. Journal of Quaternary Science, Burnt Mill, Harlow, England, 2: 35-58.

Sejrup, H. P., Fjæran, T., Hald, M., Beck, L., Hagen, J., Miljeteig, I., Morvik, I. \& Norvik, O. 1981. Benthonic Foraminifera in surface samples from the Norwegian Continental margin between $62^{\circ} \mathrm{N}$ and $65^{\circ} \mathrm{N}$. Journal of Foraminiferal Research, Lawrence, Kansas, 11: 277-295.

Shackleton, N. J., Backman, J., Zimmerman, H., Kent, D. V., Hall, M. A., Roberts, D. G., Schnitker, D., Baldauf, J. G., Desprairies,
A., Homrighausen, R., Huddlestun, P., Keene, J. B., Kaltenbach, A. J., Krumsiek, K. A. O., Morton, A. C., Murray, J. W. \& Westberg-Smith, J. 1984. Oxygen isotope calibration of the onset of ice-rafting and history of the glaciation in the North Atlantic region. Nature, London, 307: 620-623.

Tappan, H. 1951. Northern Alaska index Foraminifera. Contributions from the Cushman Foundation for Foraminiferal Research, Lawrence, Kansas, 2, pt. 1: 1-8.

Vilks, G. 1969. Recent foraminifera in the Canadian Arctic: Micropaleontology, New York, 15: 35-60 